\title{
THE SERUM PROTEIN LEVELS OF NEWBORN AFRICAN INFANTS
}

\author{
BY \\ M. W. STANIER and M. D. THOMPSON* \\ From the Departments of Physiology and Medicine, Makerere College, and Mulago Hospital, Kampala, Uganda
}

(RECEIVED FOR PUBLICATION NOVEMBER 24, 1953)

It has been shown (Holmes, Stanier, Semambo and Jones, 1951) that the concentration of $\gamma$-globulin in the serum of apparently healthy adult Africans is considerably higher than that of Europeans. It is also known (Longsworth, Curtis and Pembroke, $1945)$ that, in white infants, the level of $\gamma$-globulin of the serum of umbilical cord blood is higher than that of the maternal blood taken on the day of delivery. The question arises whether the newborn African infant has as high a level of $\gamma$-globulin as the adult African, or whether it is born with the same level of $\gamma$-globulin as the white infant, and subsequently increases its $\gamma$-globulin to the African adult level. This question was particularly interesting because unpublished observations by one of us (M.D.T.) suggested that apparently healthy African infants aged 2-4 years, without active infections and without evidence of malnutrition, had $\gamma$-globulin levels nearly as high as those of adult Africans.

Certain mammals are known to absorb large amounts of $\gamma$-globulin from the colostrum and early milk. Thus, Hansen and Phillips (1947) showed that the serum of the calf at birth contained no protein with the mobility of $\gamma$-globulin, but such a protein rapidly appeared if the animal was fed colostrum within 24 hours of birth. Similarly, Mason, Dalling and Gordon (1930) measured antibodies of ewe's serum and colostrum and lamb's serum, and showed that the lamb obtained its antibody only by suckling. As it is now known that antibodies are modified $\gamma$-globulins (Tiselius and Kabat, 1939), this must have meant an increase in the lamb's $\gamma$-globulin level. It is highly improbable that such a process occurs in man, but it would be useful to exclude this possibility, which might be invoked to account for the high $\gamma$-globulin levels found even in young African children.

Another difference in the serum protein pattern of apparently normal adult Africans from the

\footnotetext{
* Member of staff, Medical Research Council.
}

generally accepted normal figures is the lower level of serum albumin. This probably has a nutritional cause as the albumin levels increase and approach the European mean when the subjects are placed on a good diet (Holmes et al.). Longsworth et al. found in white subjects that whereas the mean albumin level of cord blood was close to that of normal adults, the albumin level of maternal blood was lower, a fact suggesting that the foetus has priority over the mother if the protein intake is limited. It would be of interest to find whether the low protein diet taken in this part of Uganda by all Africans, including pregnant women, is reflected in the albumin levels of the newborn.

Our first aim, therefore, was to repeat on African infants the observations made by Longsworth $e t$ al. on white infants. Later, we studied serum proteins in early neonatal life in order to exclude the possibility that infants may absorb globulins from colostrum and early milk.

\section{Material and Methods}

Blood from the umbilical cord was collected in clean, dry centrifuge tubes at the time of delivery from fullterm infants born by normal delivery in the maternity wards of Mulago Hospital. The blood was allowed to clot, and centrifuged, and the serum was separated within 24 hours of the birth. The serum was stored in an ice box until analysed, which was not more than two days after the birth. A blood sample was taken from an arm vein of the mother on the day of delivery or the day after, and treated in the same way. For a later series of observations, blood was taken from the umbilical cord of infants delivered by caesarean section, and from the same infant, by fontanelle puncture, some days later, as late as possible before its discharge from hospital. In the interval, all the infants were breast fed and sucked well.

Serum proteins were measured by the Antweiler micro-electrophoresis apparatus, using barbiturate buffer $p \mathrm{H} 8 \cdot 6$, ionic strength $0 \cdot 12$, the dialysed serum being diluted 1 in 4 before analysis; total protein concentration and the percentages of each fraction could be obtained directly from the electrophoresis diagram. 
TABLE 1

ANALYSIS OF SAMPLES OF CORD AND MATERNAL BLOOD

\begin{tabular}{|c|c|c|c|c|c|c|c|}
\hline \multicolumn{4}{|c|}{ Cord Blood } & \multicolumn{4}{|c|}{ Maternal Blood } \\
\hline \multirow[b]{2}{*}{ Protein $(\mathrm{g} . / 100 \mathrm{ml})}$. & \multicolumn{2}{|c|}{ Africans } & \multirow{2}{*}{$\begin{array}{l}\text { Findings of } \\
\text { U.S. Workers }\end{array}$} & \multicolumn{3}{|c|}{ Africans } & \multirow{2}{*}{ Findings of U.S. Workers } \\
\hline & Mean & Range & & Mean & & Range & \\
\hline $\begin{array}{l}\text { Total } \\
\text { Albumin } \\
\alpha \text {-globulin } \\
\beta \text {-globulin } \\
\gamma \text {-globulin }\end{array}$ & $\begin{array}{l}5 \cdot 31 \\
3 \cdot 26 \\
0 \cdot 73 \\
0 \cdot 26 \\
1 \cdot 03\end{array}$ & $\begin{array}{l}4 \cdot 80-6 \cdot 48 \\
2 \cdot 80-4 \cdot 19 \\
0 \cdot 37-0 \cdot 98 \\
0 \cdot 11-0 \cdot 43 \\
0 \cdot 66-1 \cdot 52\end{array}$ & $\begin{array}{l}6 \cdot 18 \\
3 \cdot 82 \\
0 \cdot 78 \\
0 \cdot 60 \\
0 \cdot 97\end{array}$ & $\begin{array}{l}5 \cdot 61 \\
2 \cdot 45 \\
0 \cdot 98 \\
0 \cdot 75 \\
1 \cdot 42\end{array}$ & 1 & $\begin{array}{l}4 \cdot 44-7 \cdot 06 \\
1 \cdot 93-3 \cdot 22 \\
0 \cdot 73-1 \cdot 33 \\
0 \cdot 42-1 \cdot 07 \\
0 \cdot 89-1 \cdot 97\end{array}$ & $\begin{array}{l}7 \cdot 17 \\
3 \cdot 56 \\
1 \cdot 26 \\
1 \cdot 62 \\
0 \cdot 72\end{array}$ \\
\hline $\begin{array}{c}\text { Protein }(\% \text { of total }) \\
\text { Albumin } \\
\alpha \text {-globulin } \\
\beta \text {-globulin } \\
\gamma \text {-globulin }\end{array}$ & $\begin{array}{r}61 \cdot 5 \\
13 \cdot 5 \\
4 \cdot 9 \\
20 \cdot 1\end{array}$ & $\begin{array}{r}54 \cdot 4-70 \cdot 8 \\
5 \cdot 7-19 \cdot 0 \\
2 \cdot 2-8 \cdot 2 \\
12 \cdot 8-27 \cdot 3\end{array}$ & $\begin{array}{r}61 \cdot 9 \\
12 \cdot 7 \\
9 \cdot 7 \\
15 \cdot 7\end{array}$ & $\begin{array}{l}43 \cdot 7 \\
17 \cdot 6 \\
13 \cdot 5 \\
25 \cdot 2\end{array}$ & : & $\begin{array}{r}37 \cdot 5-48 \cdot 5 \\
13 \cdot 0-25 \cdot 4 \\
7 \cdot 3-17 \cdot 6 \\
16 \cdot 8-30 \cdot 9\end{array}$ & $\begin{array}{r}49 \cdot 6 \\
17 \cdot 8 \\
22 \cdot 6 \\
9 \cdot 9\end{array}$ \\
\hline
\end{tabular}

\section{Results}

In the first series, 14 samples of cord blood and 10 samples of maternal blood were analysed. (The sera from four of the mothers had to be rejected on account of haemolysis.) The results are shown in Table 1 . In each case, the mean figures obtained by the American workers are shown for comparison. The first group of figures refer to absolute concentrations of the fractions in $\mathrm{g} . / 100 \mathrm{ml}$., the second to percentages of the total protein formed by each fraction. 'Alpha-globulin' is the sum of the $a-1$ and $\alpha-2$ fractions.

The difference between the maternal and foetal albumin concentrations of the Africans is highly significant ( $t$ for the difference of means is $4 \cdot 8$, $\mathrm{p}=<0.001)$. The difference between the maternal and foetal $\gamma$-globulin level may also be considered significant $(\mathrm{t}=2 \cdot 6, \mathrm{p}=0 \cdot 05-0 \cdot 02)$. That is, African newborn infants have a significantly higher albumin level and lower $\gamma$-globulin level than their mothers. The difference in the $\beta$-globulin (lower in the infants) was too obvious to require recourse to the $t$ test.

A comparison with the figures obtained by the American workers is of some interest. In the cord blood samples, the mean $\alpha$-globulin is not significantly different nor is difference in mean $\gamma$-globulin significant ( $t$ for the difference of means is 0.66 ). Both the albumin and the $\beta$-globulin levels, however, are considerably lower in the African cord blood: for the difference in mean albumin levels, $t=4.3$ and $p=0.001$. (The difference in $\beta$-globulin levels was too great to necessitate using the $t$ test.) In the case of maternal serum, all proteins except the $\gamma$-globulin show a significantly lower level in the Africans. The significance of the difference of mean $\alpha$-globulin levels, which might be in doubt on inspection, was tested when $\mathrm{t}=3 \cdot 2$ and $\mathrm{p}=0 \cdot 01-0 \cdot 001$. The mean $\gamma$-globulin level is about twice as high in African mothers as in white mothers, an obviously significant difference.

For the second series of observations, the results are shown in Table 2, together with the interval between taking the cord blood and the second sample. The two 3-month-old infants had been carefully looked after, and had received prophylactic anti-malarial treatment ('daraprim') since birth. Figures in brackets refer to percentages of the total protein, the others to concentration in $\mathrm{g} . / 100 \mathrm{ml}$. There is clearly no increase in $\gamma$-globulin during

TABLE 2

RESULTS OF SECOND SERIES OF OBSERVATIONS

\begin{tabular}{|c|c|c|c|c|c|c|c|c|c|c|c|c|c|}
\hline \multirow[b]{2}{*}{$\begin{array}{c}\text { Baby } \\
\text { of }\end{array}$} & \multirow[b]{2}{*}{$\begin{array}{c}\text { Total } \\
\text { (g. } / 100 \mathrm{ml} .)\end{array}$} & \multicolumn{2}{|c|}{ Cord Blood } & \multirow[b]{2}{*}{$\alpha$} & \multirow[b]{2}{*}{$\beta$} & \multirow[b]{2}{*}{$\gamma$} & \multicolumn{4}{|c|}{ Second Sample } & \multirow[b]{2}{*}{$\beta$} & \multirow[b]{2}{*}{$\gamma$} & \multirow[t]{2}{*}{ Interval } \\
\hline & & Albumin & $\begin{array}{c}\text { Total } \\
\text { Globulin }\end{array}$ & & & & Total & Albumin & $\begin{array}{c}\text { Total } \\
\text { Globulin }\end{array}$ & $\alpha$ & & & \\
\hline T.M. & $4 \cdot 82$ & $\begin{array}{r}2 \cdot 95 \\
(61 \cdot 4)\end{array}$ & $\begin{array}{l}1 \cdot 87 \\
(38 \cdot 6)\end{array}$ & $\begin{array}{l}0 \cdot 31 \\
(6 \cdot 7)\end{array}$ & $\begin{array}{l}0 \cdot 25 \\
(5 \cdot 1)\end{array}$ & $\begin{array}{c}1 \cdot 29 \\
(26 \cdot 8)\end{array}$ & $4 \cdot 25$ & $\begin{array}{r}3 \cdot 14 \\
(74)\end{array}$ & $\begin{array}{l}1 \cdot 11 \\
(26)\end{array}$ & $\begin{array}{l}0.40 \\
(9 \cdot 5)\end{array}$ & $\begin{array}{l}0 \cdot 12 \\
(2 \cdot 9)\end{array}$ & $\begin{array}{c}0 \cdot 58 \\
(13 \cdot 6)\end{array}$ & 12 days \\
\hline N.N. & $5 \cdot 00$ & $\begin{array}{c}3 \cdot 19 \\
(63 \cdot 9)\end{array}$ & $\begin{array}{l}1 \cdot 81 \\
(36 \cdot 1)\end{array}$ & $\begin{array}{l}0 \cdot 51 \\
(10 \cdot 2)\end{array}$ & $\begin{array}{l}0 \cdot 37 \\
(7 \cdot 4)\end{array}$ & $\begin{array}{r}0.93 \\
(18 \cdot 5)\end{array}$ & $3 \cdot 81$ & $\begin{array}{r}2 \cdot 34 \\
(61 \cdot 7)\end{array}$ & $\begin{array}{c}1 \cdot 47 \\
(38 \cdot 3)\end{array}$ & $\begin{array}{l}0 \cdot 44 \\
(11 \cdot 7)\end{array}$ & $\begin{array}{l}0 \cdot 29 \\
(7 \cdot 6)\end{array}$ & $\begin{array}{r}0.73 \\
(19)\end{array}$ & 8 days \\
\hline M. & $4 \cdot 32$ & $\begin{array}{r}2 \cdot 96 \\
(68 \cdot 4)\end{array}$ & $\begin{array}{r}1 \cdot 36 \\
(31 \cdot 6)\end{array}$ & $\begin{array}{l}0 \cdot 40 \\
(9 \cdot 4)\end{array}$ & $\begin{array}{l}0 \cdot 14 \\
(3 \cdot 2)\end{array}$ & $\begin{array}{r}0.82 \\
(19)\end{array}$ & $4 \cdot 40$ & $\begin{array}{c}3 \cdot 08 \\
(70 \cdot 2)\end{array}$ & $\begin{array}{c}1 \cdot 32 \\
(29 \cdot 8)\end{array}$ & $\begin{array}{l}0 \cdot 49 \\
(11 \cdot 1)\end{array}$ & $\begin{array}{l}0 \cdot 23 \\
(5 \cdot 3)\end{array}$ & $\begin{array}{r}0 \cdot 59 \\
(13 \cdot 4)\end{array}$ & 9 days \\
\hline J.O. & $5 \cdot 35$ & $\begin{array}{c}3 \cdot 13 \\
(58 \cdot 5)\end{array}$ & $\begin{array}{c}2 \cdot 22 \\
(41 \cdot 5)\end{array}$ & $\begin{array}{l}0 \cdot 76 \\
(14 \cdot 3)\end{array}$ & $\begin{array}{l}0 \cdot 18 \\
(3 \cdot 4)\end{array}$ & $\begin{array}{c}1 \cdot 27 \\
(23 \cdot 8)\end{array}$ & $4 \cdot 10$ & $\begin{array}{r}2 \cdot 46 \\
(60 \cdot 2)\end{array}$ & $\begin{array}{r}1 \cdot 64 \\
(39 \cdot 8)\end{array}$ & $\begin{array}{l}0 \cdot 71 \\
(17 \cdot 3)\end{array}$ & $\begin{array}{r}0.49 \\
(12)\end{array}$ & $\begin{array}{l}0.44 \\
(10 \cdot 4)\end{array}$ & 12 weeks \\
\hline F.B. & $4 \cdot 87$ & $\begin{array}{c}3 \cdot 32 \\
(68 \cdot 1)\end{array}$ & $\begin{array}{c}1 \cdot 55 \\
(31 \cdot 9)\end{array}$ & 0.65 & 0.14 & 0.76 & - & $3 \cdot 90$ & - & $1 \cdot 25$ & - & $0 \cdot 34$ & 12 weeks \\
\hline
\end{tabular}


the first few days or weeks of life. On the contrary, the level of this fraction fell in each case.

\section{Discussion}

The low level of serum albumin in the Africans' cord blood, and the even lower level in the mother's blood, are probably to be explained by the low level of dietary protein which is prevalent in Uganda. The extremely low level of $\beta$-globulin was an unexpected finding, particularly in view of the work of Symul (1950) who, using a chemical method of analysis, found all fractions in African cord blood close to the values obtained in European cord blood. However, our findings are in accord with those of van Oye and Charles (1951) who compared sera of African cord blood and African adults (using a chemical method) and found all fractions, but especially the $\beta$ - and $\gamma$-globulin, lower in the cord blood.

The raised $\gamma$-globulin levels of apparently normal adult Africans and of white infants suggested the possibility that the $\gamma$-globulin level of the adult African represented a survival into adult life of an infantile trait, analogous to the survival, in the adult African, of certain anatomical features of infancy (Scott Brown, 1953). The above results exclude this possibility. Whereas the white infant is born with a $\gamma$-globulin level higher than its mother's, the African infant is born with a $\gamma$-globulin level lower than its mother's or than adult male Africans. The idea that a raised level of $\gamma$-globulin is an inherited racial trait is not absolutely excluded by these results, since inherited characters are not necessarily present at birth; the results, however, give the idea no support. It appears from the second series of estimations that, as with white infants (Poyner-Wall and Finch, 1950) there is a tendency for total protein and total globulin levels to fall during the first few weeks of life. There is clearly no sudden increase in $\gamma$-globulin as a result of suckling.

The question whether the greater percentage of $\gamma$-globulin in African as compared with European cord blood has any significance is a difficult one. It has been suggested (Mackey, 1953) that in a country such as Africa where many infections are hyper- endemic, there would be, and has already been, selection in favour of the ability to produce antibodies readily. Thus, one might conjecture that if the supply of dietary protein is short, antibodies are made in preference to certain other serum protein fractions-say $\beta$-globulin. This interpretation is, however, highly speculative in view of the fact that so far there is not the slightest evidence that the extra $\gamma$-globulin of adult Africans is antibody globulin.

\section{Summary}

The serum protein fractions of African umbilical cord blood, maternal blood, and the blood of young African infants were measured by micro-electrophoresis.

The main differences, as compared with corresponding data on white persons, were significantly lower mean levels of albumin and $\beta$-globulin. In the maternal blood, mean levels of all protein fractions were lower in Africans, except for that of $\gamma$-globulin which was about twice as high. Thus, whereas in white persons the mean $\gamma$-globulin level of cord blood is slightly higher than that of maternal blood, in Africans it was significantly lower.

The mean $\alpha$ - and $\gamma$-globulin levels at birth were found to be the same as for white persons, and there was no increase in $\gamma$-globulin as a result of suckling.

The interpretation of these findings has been discussed.

We are grateful to the Medical Superintendent, Mulago Hospital, for facilities, and to Dr. C. Rendle-Short and the staff of the maternity wards for cooperation in the collecting of blood samples.

\section{REFERENCES}

Brown, J. Scott (1953). E. Afr. med. J., 30, 145.

Hansen, R. G. and Phillips, P. H. (1947). J. biol. Chem., 171, 223 Holmes, E. G., Stanier, M. W., Semambo, Y. B. and Jones, E. R (1951). Trans. roy. Soc. trop. Med. Hyg., 45, 371.

Longsworth, L. G., Curtis, R. M. and Pembroke, R. H. (1945) J. clin. Invest., 24, 46 .

Mackey, J. P. (1953). E. Afr. med. J., 30, 13.

Mason, J. H., Dalling, T. and Gordon, W. S. (1930). J. Path. Bact., 33, 783.

Oye, E. van and Charles, P. (1951). Ann. Soc. belge Méd. trop., 31, 403 .

Poyner-Wall, P. and Finch, E. (1950). Archives of Disease in Childhood, 25, 129.

Symul, F. (1950). Ann. Soc. belge Méd. trop., 30, 295.

Tiselius, A. and Kabat, E. A. (1939). J. exp. Med., 69, 119. 